\title{
The Police's role in the field of improving functioning fuel sector as an element of energy safety management in Poland
}

\author{
MARCIN JURGILEWICZ \\ Department of Safety Sciences \\ Rzeszow University of Technology \\ Al. Powstancow Warszawy 12, Rzeszow 35-959 \\ POLAND \\ MARLENA LOREK \\ Department of Safety Sciences \\ Rzeszow University of Technology \\ Al. Powstancow Warszawy 12, Rzeszow 35-959 \\ POLAND \\ ARSEN OVSEPYAN \\ Polish-Armenian Foundation \\ Wspolna 61/107, 00-687 Warszawa \\ POLAND \\ MARIUSZ KUBIAK \\ Institute of Security Sciences \\ University of Natural Sciences and Humanities in Siedlce \\ ul. Zytnia 39 08-110 Siedlce \\ POLAND
}

\begin{abstract}
The energy sector is an example of an unusual branch of the economy whose success largely depends on the amount of energy carriers owned by a given country. Paying attention to Poland, it should be noted that next to hard coal, which is the largest quantity of raw material, the role of oil and natural gas is steadily increasing. Energy security gives the opportunity for development in individual countries only if it can function and satisfy basic goods that allow economic prosperity. These goods include, but are not limited to, energy resources, which may determine the prosperity of individual economic sectors. In turn, energy carriers along with other raw materials decide about the level of fuel security of the country, and thus affect the level of energy security. However, due to the existing threats to this sector, one of the important roles is played by the Police, which counteracts all criminogenic phenomena that deplete the economic benefits for the state from the fuel sector. The article is an interesting supplement to the issues raised in the journal, because it draws attention to a special problem that should be tackled not only on a national, but also international scale, so the text seems to be important from the perspective of the topics discussed. In addition, the issues raised, which are not so often discussed in the scientific literature, constitute an interesting supplement in the field of matter.
\end{abstract}

Key-Words: - Security, energy, fuel sector, police, safety, security.

Received: January 13, 2020. Revised: June 5, 2020. Re-revised: June 14, 2020. Accepted: June 16, 2020. Published: June 17, 2020

\section{Introduction}

Security is most often understood as the lack of threats felt by individuals, larger social groups and countries. Although there is no absolute security, because it refers to a specific entity at a specific time, nevertheless, strengthening security is recognized as the leading task of the state, which is obliged to create appropriate mechanisms enabling the proper implementation of this goal. On the basis of scientific literature, various security divisions can be found which arose on the basis of different 
criteria, although the typology of this term is mainly determined by categories such as the subject, the environment and the relationship of the subject and the environment with space-time. Recalling security divisions, it is possible to point to such categories as international and national security, internal and external, etc. In turn, as part of internal security, you can distinguish other categories that, specified by the adjective, orientate towards the protected good, i.e. energy security, ecological security, cultural security or fuel security [1].

It is worth emphasizing that the Police is one of the leading formations that watches over the level of internal security of the Republic of Poland. The police, thanks to such a wide range of tasks, can reliably perform their duties in the field of counteracting for various types of crime, and thus conducts a continuous control process over the security of Poland's territory. Increasing stability in the country through adequate security has an impact on public awareness and the lack of threat will allow tangible benefits of involvement in work for the development of the energy sector.

Economic stability is a guarantee for energy security, because the state will be able to fully achieve the goals related to new energy extraction technologies. The end of the 90s was a flourishing of criminal groups in the territory of the Republic of Poland, which is why law enforcement agencies had to develop their activities in the field of counteracting for drug, criminal and economic groups.

\section{Energy security and fuel security - literature review}

According to the content of the National Security Strategy of the Republic of Poland from 2014, energy is one of the most important national interests of the state in the field of security. The basic factors of the country's energy security include access to energy resources, including abroad, diversification of sources and directions of fuel supplies, as well as the construction of new capacities based on various generation technologies, allowing for balancing domestic energy demand.

Generally, in the energy sector literature the most important development barriers are the complexity of technologies, climate change, climate policy, the shortage of qualified personnel, the lack of knowledge and experience in marketing and communication, the lack of know-how technology [2-8] When creating a state energy policy, it should be built in such a way that these barriers do not constitute obstacles to the further development of the energy sector. Now this situation is additionally hampered by the Covid-19 epidemic, it must be take all measures to ensure secure delivery to all recipients. The country's energy policy is therefore focused on ensuring the proper development of production, transmission and storage infrastructure, as well as stimulating investment in modern, energy-saving technologies and products, as well as reducing dependence on the supply of energy raw materials [9]. It should also be added that due to the dependence of EU countries on imports of energy raw materials, it is necessary to ensure energy security as an uninterrupted and diversified source of natural gas and oil supplies. The consequences in this area are also the effects of limiting the transport of crude oil through the territory of the Republic of Poland to the countries of Central Europe, as well as the import of this raw material to the country using the existing infrastructure. In turn, the opportunity is to build a common European energy market, to maintain solidarity in the behavior of member states, to create uniform rules and instruments to increase energy security. The diversification of roads and sources of supply of raw materials, using unconventional deposits and sources of production, also contributes to improving the country's energy security. based on nuclear energy, as well as ensuring stability of energy supply through the development of generating and network infrastructure [9]. The strategic task of the state for ensuring energy security is to launch the extraction of energy resources from domestic unconventional deposits, development of network and production infrastructure based on coal, nuclear and gas fuels and ensuring diversified access to sources and routes of supply of energy resources [10]. The liberalization of energy markets and creating conditions for the implementation of investments in the energy sector are also becoming key.

The National Security Strategy of the Republic of Poland of 2014 also indicates that state security requires inter-ministerial coordination, taking into account the division of powers in the Council of Ministers in the field of energy policy and ensuring the state's influence on its implementation by energy enterprises, which will have a real impact on quick and effective response in case of threats on energy markets. It is also necessary for the state to maintain control over the key infrastructure of the fuel and energy sector and to extend supervision and control over the wealth of geological resources of the state [9]. 
In the Act of 10 April 1997, the Energy Law [11] whose main goal is to create conditions for sustainable development of the country, ensure energy security, economical and rational use of fuels and energy, develop competition, as well as counteract the negative effects of natural monopolies, taking into account the requirements of environmental protection, obligations arising from international agreements and balancing the interests of energy enterprises and consumers of fuels and energy, in Art. 3 point 16 upe, the term energy security was defined. This term means the state of the economy enabling coverage of current and longterm demand of consumers for fuels and energy in a technically and economically justified manner, while maintaining the requirements of environmental protection. A similar definition, however, emphasizing the detailed aspects of security, appears in the Annex to the Energy Policy of the State until 2030. The term energy security also appears in EU acts, e.g. Directive 2005/89, Directive 2004/67, or Directive 2006/67, whose common element is guaranteeing security of supply for all energy carriers while respecting the principles of competition in the internal market as well as national markets. Similarly, the UN report on the energy market defines the concept of energy security, designating the term in the category of energy availability at all times, in various forms, as well as in sufficient quantity and at a reasonable price. In turn, scientific literature indicates that energy security consists of security of fuel and energy supplies, as well as operational security of the network [12].

Security of electricity supply is the ability of the electricity system to ensure security of the electricity grid and balancing electricity supply with the demand for it, while security of electricity grid operation means uninterrupted operation of the electricity grid, as well as meeting the requirements in the field of quality parameters of electricity and quality standards customer service, including permissible interruptions in the supply of electricity to final customers, in foreseeable operating conditions of this network. In turn, the threat to security of electricity supply means the condition of the electricity system or parts of it, preventing the security of electricity network operation or balancing electricity supplies with the demand for that energy [13] Regarding the threat to security of electricity supply, it is worth adding that this issue was included in one of the documents - the Green Paper, indicating that the physical security of Europe's energy infrastructure against threats, i.e. natural disasters, terrorism and protection against threats, including interruption of supplies - is decisive for predictability. Therefore, the development of intelligent electrical networks, demand management together with increasing energy generation increases the likelihood of assistance in the event of a sudden shortage [12]

Considering the above, it can be stated that the country's energy security is currently one of the key areas co-defining the security of the state, as well as the conditions for economic development. It depends on many factors. These include: the origin of energy supply sources, their coordination and diversification, ownership of energy sector companies, fuel storage within the country, as well as the stability of the situation inside and outside the country. The level of energy security is also influenced by, among others factors, e.g. climate (e.g. storms), social (e.g. terminal blockades), technical (e.g. industrial plant failures). Ensuring energy security by the state should primarily consist in creating a set of actions enabling the functioning of a legal and economic system, thanks to which supply reliability would be ensured including compliance with requirements and restrictions resulting not only from competitiveness, but also environmental protection [14]. In turn, next to the concept of energy security, there is also the concept of fuel security. In the Act of 16 February 2017 on stocks of crude oil, petroleum products and natural gas, and rules of conduct in situations of threat to national fuel security and disturbances on the oil market [15] it is said that fuel security is a condition enabling the current coverage of the customers' demand for crude oil, petroleum products and natural gas, in a given size and time, to the extent that the economy can function properly. And here the important role is played by formations authorized to take actions to counteract threats directed at the energy sector, which may include Police.

\section{Conditions regarding the functioning of the Police}

Considering the above, the definitions of the terms energy security or fuel security materialize the problem of dangers for these areas, justifying the actions of entities authorized to counteract these threats. One of the entities implementing tasks to ensure state security, including the fuel and energy sector, is the Police. This is an example of a uniformed formation having a relatively broadest scope of competence among other state services that 
are used by its officers in protecting people's security and to maintain public safety and order. The basic legal act regulating the legal status of this formation is the Act of 6 April 1990 on the Police. [16].Police were included in the abovementioned of the Act, nevertheless the police also carry out tasks specified in other legal acts, thus it is not possible to present situations in which this formation could not take action if they were directed at ensuring public safety and order. The catalog of tasks specified in the Police Act is open [17], however, the main tasks of the Police include:

- protecting the lives and health of people and property against unlawful attacks affecting these goods;

- protection of public safety and order, including ensuring peace in public places and in means of public transport and public transport, in road traffic and in waters intended for general use;

- initiating and organizing activities aimed at preventing committing crimes and offenses as well as criminogenic phenomena and cooperating in this respect with state organs, self-government bodies and social organizations;

- conducting counter-terrorism activities within the meaning of the Act of 10 June 2016 on anti-terrorist activities;

- detecting offenses and prosecution of their perpetrators;

- monitoring compliance with order and administrative provisions related to public activity or in public places;

- cooperation with the police of other countries and their international organizations, as well as with EU bodies and institutions on the basis of international agreements and arrangements as well as separate provisions;

- collecting, processing and forwarding criminal information;

- maintaining data sets containing information collected by authorized bodies about fingerprints of persons, unidentified fingerprints from crime scenes and the results of deoxyribonucleic acid (DNA) analysis [18].

The police perform operational, reconnaissance, investigation and administrative and order activities in order to: identify, prevent and detect crimes and offenses; search for people hiding from law enforcement or judicial authorities, as well as the search for people who, as a result of an event preventing their location, should be found in order to protect their life, health or freedom. Policemen carrying out statutory tasks have the right to:

- identification of persons in order to establish their identity;

- detaining persons in the manner and cases specified in the provisions of the Act - Code of Criminal Procedure and other acts;

- detention of persons deprived of liberty who, on the basis of the authorization of the competent authority, left the detention center or the prison and did not return to him within the prescribed period;

- detaining persons posing an obvious direct threat to human life or health, as well as property;

- taking fingerprints or smears from the mucous membranes of cheeks from persons: in the mode and cases specified in the provisions of the Code of Criminal Procedure and the Act on the treatment of persons with mental disorders posing a threat to life, health or sexual freedom of other persons, in order to identify persons with an unknown identity and persons attempting to hide their identity if it is not possible to establish identity in another way, or with their consent to identify missing persons or human corpses of unknown identity;

- taking fingerprints or biological material from human corpses of unidentified identity;

- searching people and rooms in the mode and cases specified in the provisions of the Code of Criminal Procedure and other acts;

- observation and recording by technical means of an image from rooms intended for detainees or persons brought for sobering up, police children's rooms, transition rooms and temporary transition rooms;

- carrying out personal checks, as well as reviewing the contents of luggage and checking cargo in ports and stations, as well as in land, air and water transport, if there is a reasonable suspicion of committing a criminal offense under pain of punishment;

- observing and recording by technical means the image of events in public places, and in the case of operational-reconnaissance and administrative-order activities undertaken pursuant to the Act - also and the sound accompanying these events; 
- demand the necessary assistance from state institutions, government administration and local government bodies, as well as entrepreneurs operating in the field of public utility; these institutions, bodies and entrepreneurs are obliged, within the scope of their activity, to provide this assistance, within the scope of applicable law;

- applying for the necessary help to other entrepreneurs and social organizations, as well as asking for emergency assistance to any person for emergency assistance, in accordance with applicable law [1].

In accordance with art. 15 uop, against a detained person who obviously poses a direct threat to human life or health, as well as property, have the rights provided for a detained person in the Code of Criminal Procedure, while detention of such a person may be applied only if other measures proved to be pointless or ineffective. This person may be presented, photographed or fingerprinted only if his identity cannot be determined by other means, and should be immediately subjected to a medical examination or medical first aid if necessary.

It should also be emphasized that police officers have other special powers used to combat organized crime as well as other dangerous forms of organized crime. When performing operational and reconnaissance activities undertaken by the Police to prevent, detect, determine the perpetrators, as well as obtain and record evidence prosecuted by public accusation, intentional crimes:

- against life as defined in art. $148-150$ of the Penal Code;

- referred to in Article 134, art. $135 \S 1$, art. $136 \S 1$, art. $156 \S 1$ and 3 , art. $163 \S 1$ and 3 , art. $164 \S 1$, art. $165 \S 1$ and 3 , art. 166 , art. 167 , art. $173 \S \mathrm{I}$ and 3 , art. 189 , art. 189a, art. 21 la, art. 223, art. $228 \S 1$ and 35, art. $229 \S 1$ and 3-5, art. $230 \S 1$, art. 230a $\S 1$, art. $231 \S 2$, art. 232 , art. 245 , art. 246 , art. $252 \S 1-3$, art. 258 , art. 269, art. 280,282 , art. $285 \S 1$, art. $286 \S \mathrm{I}$, art. $296 \S$ 1-3, art. 296a $\S 1,2$ and 4, art. $299 \S 1-6$ and art. $310 \S 1,2$ and 4 of the Penal Code;

- referred to in Article 46 section 1,2 and 4, art. 47 and art. 48 paragraph 1 and 2 of the Sporting Act;

- against economic turnover, as defined in art. 297-306 of the Penal Code, causing material damage or directed against property, if the amount of damage or value of the property exceeds fifty times the amount of the lowest remuneration for work determined on the basis of separate provisions;

- against sexual freedom and decency, when the victim is a minor, or when the pornographic content referred to in art. 202 $\mathrm{Kk}$; include the participation of a minor;

- fiscal, if the value of the object of the act or reduction of public law receivables exceed fifty times the amount of the lowest remuneration for work determined on the basis of separate provisions;

- tax, referred to in art. $107 \S 1$ of the Fiscal Penal Code;

- illegal manufacture, possession or trade in arms, ammunition, explosives, narcotic drugs or psychotropic substances or their precursors as well as nuclear and radioactive materials;

- referred to in Article 8 of the Act Regulations introducing the Penal Code; referred to in Article 43-46 of the Act on the collection, storage and transplantation of cells, tissues and organs;

- prosecuted under international agreements and arrangements, when other measures have proved ineffective or are of no use, the regional court may, by way of a resolution, order operational control, upon a written request of the Chief of Police or the Commander of the Central Bureau of Investigation, submitted after obtaining the written consent of the Prosecutor General, or on a written request provincial police commander, submitted after obtaining the written consent of the district prosecutor competent for the seat of the applicant Police authority [1].

Also, when you need to take at least one of the following actions:

- enforce the required by law behavior in accordance with the order issued by the police officer;

- repelling a direct, unlawful attempt on the life, health or freedom of a police officer or another person;

- counteracting activities that directly aim at assassinating a police officer or another person, or violating public order or security;

- counteracting a direct attack on areas, objects or devices protected by a police officer; 
- $\quad$ protect order or security in areas or facilities protected by a police officer; preventing the destruction of property;

- ensure convoy or lead safety;

- catching a person, thwarting their escape or chasing that person;

- detaining a person, thwarting their escape or chasing that person;

- passive overcoming or resistance or counteracting activities aimed at selfaggression, then police can use or use direct coercion measures [1].

\section{Police activities in combating threats to fuel security - Results}

When assessing the police activity in the field of combating threats to fuel security, statistical material from the Police Headquarters was used. Statistical data, which are listed below, refer to trading in fuels, alcohol and tobacco products in 2013-2019. And so in the years 2013-2019, i.e. in total over 7 years, the Police initiated 13,494 proceedings in the abovementioned scope, of which a total of 10919 offenses were identified, and a total of 10441 offenses were detected. Chart 1 below illustrates the scale of the discussed problem.

Chart 1. Number of proceedings initiated, total number of crimes identified and detected by the Police in the area of trade in fuels, alcohol and tobacco products in 2013-2019.

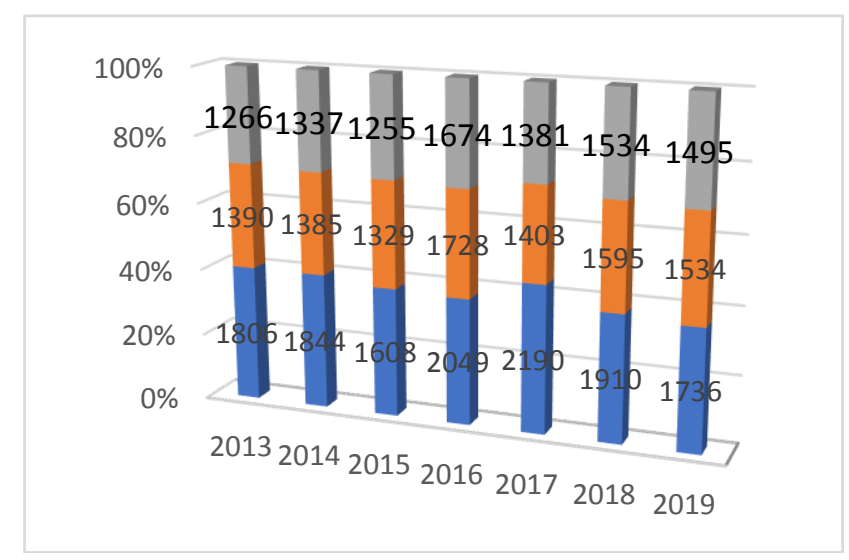

$\square$ Happy proceedings

Proceedings found

Detected offenses

Source: own study based on KGP statistical materials.
The tendency related to the detection of offenses related to trading in fuels as well as alcohol and tobacco products is in principle upward, although in 2018 and 2019 a decrease in the detection of the abovementioned was recorded. crimes.

In the same period, there was a decrease in the initiation of proceedings by police officers in the discussed area, as was the case with the determination of committed crimes. However, it should be emphasized that as a result of the work of policemen in combating the so-called fuel crime, there are fewer and fewer losses to the state budget. And so since 2015, when there were 464988313 million losses for the state budget - the largest in 2013-2019. In turn, every year, as a rule, there is a systematic decrease in losses. It is worth adding that the introduction of relevant legal regulations has increased the possibilities in the fight against the shadow economy. And so the uniformed services increased, among others its control activities, as well as staff resources increased, which positively affected the activities in the discussed area.

However, regarding the problem of losses that were incurred in connection with the category of crimes discussed, the scale of the phenomenon is illustrated in Chart 2.

Chart 2. The number of losses in PLN registered by the Police in 2013-2019

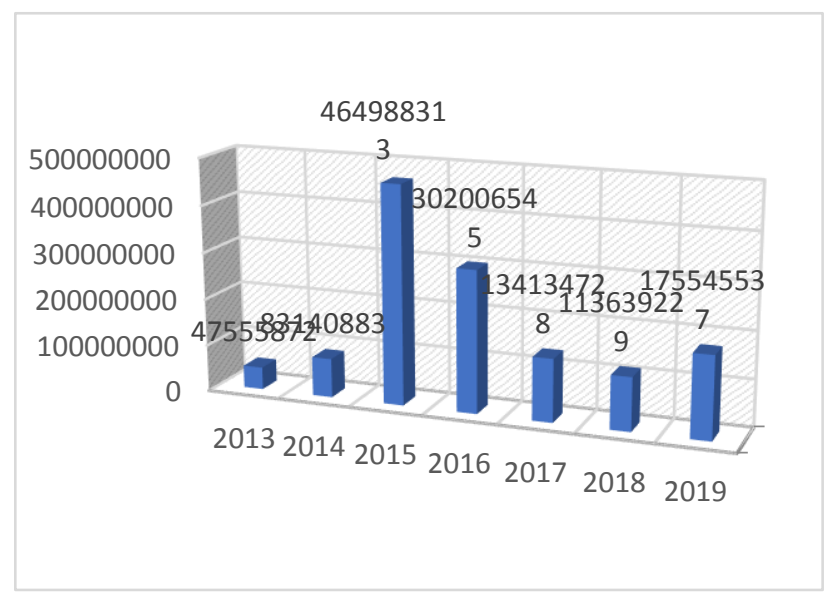

Source: own study based on statistical materials of the Police.

Crimes in the trading of fuels, alcohol and tobacco products, as evidenced by the cited statistical data, constitute one of the special threats 
to the fuel security of the state, because they carry numerous losses to the national budget. Their tendency, although in principle a downward trend, currently remains at a level that requires the police to take preventive action. Therefore, the police's activity, in particular the officers of this formation taking operational and reconnaissance and investigative activities make it possible to optimally counteract this phenomenon. The police in this regard should also cooperate with other services, including customs and tax services, as well as take numerous preventive actions.

\section{Conclusion}

Preventing crime directed at trading in fuels, including alcoholic and tobacco products is a particularly important activity and a need. In this respect, the police undertake various activities that result in initiating and detecting criminogenic phenomena in the fuel sector.

As part of these activities, police cooperation with other services, not only domestic but also international, is also required. In addition, actions are also needed to coordinate the work of the Police with public administration bodies, along with shaping state policy in the area discussed, to optimizing the efect, with in turn a model of the able energy security management in the country in additon, in the 21 st century, the stope of activities of criminal groups is becoming increasingly variable in nature, w ich may be aimed at conquering significant financial benefits in a short time. Every country in the world must fully protect goods that guarantee the development of individual economic sectors, and this is only possible if the system secures revenues from Energy trading for the benefit of the state treasury. Any disturbance of the Energy sector can lead to threats that can be felt by citizens, even by increasing Energy prices. That is why the Police as an institution working to minimize threats must identify and counteract crime, $w$ ich can become a dynamically developing phenomenon not only in Poland but also in neighboring countries. The analysis carried out in the article may constitute an overview material for international recipients regarding the problem of counteracting the so-called fuel crime.

\section{References:}

[1] Jurgilewicz, M., Rola podmiotów uprawnionych do uzycia lub wykorzystania środków przymusu bezpośredniego $i$ broni palnej $w$ ochronie bezpieczeństwa i porzadku publicznego, Siedlce, 2017, pp 30-34.
[2] Cagno, E., Worrell. E., Trianni, A., \& G. Pugliese, A novel approach for barriers to industrial energy efficiency, Renewable and Sustainable Energy Reviews, Volume 19, March 2013, pp. 290-30.

[3] Dahlqvist, A., \& Soderholm,P., Industrial Energy Use, Management Practices and Price Signals: The Case of Swedish Process Industry, International Journal of Energy Economics and Policy, 2019, 9(3), pp. 30-45.

[4] del Río, P., \& Peñasco, C., \& Mir-Artigues, C.P., An overview of drivers and barriers to concentrated solar power in the European Union, Renewable and Sustainable Energy Reviews Volume 81, Part 1, January 2018, pp. 1019-1029.

[5] Di Foggia, G.D., Effectiveness of energy efficiency certificates as drivers for industrial energy efficiency projects. International Journal of Energy Economics and Policy, 6(2),2016, pp. 273-280.

[6] Foxon. T.J., Gross, R., Chase, A., Arnall, H.J., \& Anderson, D. UK innovation systems for new and renewable energy technologies: drivers, barriers and systems failures, Energy Policy Volume 33, Issue 16, November 2005, pp. 2123-2137.

[7] Meijer. L.L; Huijben, J.C.C.M., van Boxsteal A.,\& Romme, A.G.L. Barriers and drivers for technology commercialization by SMEs in the Dutch sustainable energy sector, Renewable and Sustainable Energy Reviews 112(2019), pp.114-126.

[8] Zimon, G. An Assessment of the Strategy of Working Capital Management in Polish Energy Companies, International Journal of Energy Economics and Policy, Volume 9, No 6, 2019, pp. 552-556.

[9] Strategia Bezpieczeństwa Narodowego Rzeczypospolitej Polskiej, Warszawa, 2014.

[10] Zimon, G. Financial liquidity Management Strategies in Polish Energy Sector, International Journal of Energy Economics and Policy, 2020, 10(3), pp. 365-368.

[11] Dz.U. z 2019 r. poz. 755 ze zm.

[12] Swora, M., \& Muras, Z. Prawo energetyczne. Tom I. Komentarz do art. 111s, Warszawa 2016, s. 329. World Energy Assessment: Energy and the Challenge of Sustainability, United Nations Development Programme, New York 2000.

[13] Art. 3 pkt 16-16b upe.

[14] Jurgilewicz, M., \& Protasowicki, I., Współczesne determinanty bezpieczeństwa energetycznego Unii Europejskiej [w:] 
Bezpieczeństwo Europy. Kontekst gospodarczy, T.Z. Leszczyński (red.), Kraków 2015.

[15] Płaczek, J. (ed.), Ekonomika bezpieczeństwa Państwa w zarysie, Difin, 2014, pp. 283-284.

[16] Dz.U. z 2018 r. poz. 1323 ze zm.

[17] Jurgilewicz, M. Znaczenie i zakres zadań Policji, Przeglad Prewencyjny Nr 2/2012(6), pp. 65.

[18] Lorek, M. Motywowanie w polskiej Policji, Oficyna Wydawnicza Politechniki Rzeszowskiej, Rzeszów 2017, pp. 37-38.

\section{Contribution of individual authors to the creation of a scientific article (ghostwriting policy)}

Marcin Jurgilewicz - Conceptualization

Marcin Jurgilewicz, Marlena Lorek - writingreview and editing

Arsen Ovsepyan, Mariusz Kubiak was responsible for the Statistics.

Marcin Jurgilewicz, Marlena Lorek, Arsen Ovsepyan, Mariusz Kubiak writing - original draft preparation

\section{Sources of funding for research presented in a scientific article or scientific article itself}

There is not any sources

\section{Creative Commons Attribution \\ License 4.0 (Attribution 4.0 \\ International, CC BY 4.0)}

This article is published under the terms of the Creative Commons Attribution License 4.0 